\title{
Adult onset idiopathic torsion dystonia is excluded from the DYT 1 region (9q34) in a Swedish family
}

\author{
Gösta Holmgren, Laurie Ozelius, Lars Forsgren, Bela G L Almay, Monica Holmberg, \\ Patricia Kramer, Stanley Fahn, Xandra O Breakefield
}

\begin{abstract}
A gene (DYT1) for early onset idiopathic torsion dystonia was mapped to chromosome 9q34 in non-Jewish and Jewish families. The DYT1 gene region has been excluded in other families with adult onset and cervical or cranial onset idiopathic torsion dystonia from the United States, Great Britain, and France. The role of DYT1 in a Swedish family with adult onset idiopathic torsion dystonia in four generations was examined. The disease seems to be inherited in an autosomal dominant mode with reduced penetrance in this family. There were 10 affected family members, with a mean age of onset of 27 (range 18 to 50) years. The disease showed variable expression, with focal, multifocal, and generalised forms of dystonia in different family members. Genetic analysis excluded the chromosomal region containing the DYT1 locus as being responsible for dystonia in this family.
\end{abstract}

$(\mathcal{F}$ Neurol Neurosurg Psychiatry 1995;59:178-181)

Keywords: torsion dystonia; chromosome 9; DYT 1

\section{Introduction}

Idiopathic' torsion dystonia is a fairly common involuntary movement disorder with a prevalence estimated at 3.3/1000. ${ }^{1}$ The disorder is characterised by involuntary sustained muscle contractions, often causing twisting and repetitive movements and postures, without other neurological signs and with no known cause. ${ }^{2}$ A large non-Jewish family with torsion dystonia (dystonia musculorum deformans), from northern Sweden, was described in $1966 .{ }^{3}$ Segregation analysis showed that the disorder was inherited as an autosomal dominant trait. A follow up evaluation of this nonJewish family showed a high penetrance for expression of the defective gene. ${ }^{4}$ In a single family with a clear cut pattern of inheritance it is likely that all affected members carry the same defective autosomal gene. Rigorous neurological criteria ${ }^{5}$ have been used to determine affected state in 67 family members examined by us to date.

Ozelius et al localised a gene for an early onset form of idiopathic torsion dystonia to 9q32-34 in an American non-Jewish family. ${ }^{6}$ Kramer et al found evidence for linkage to the same region in a sample of 12 Ashkenazi Jewish families with idiopathic torsion dystonia. ${ }^{7}$ This locus DYT1 seems to be responsible for most cases of classic early onset dystonia in non-Jewish families. ${ }^{8}$ Linkage disequilibrium between an extended haplotype of $9 q 34$ loci and the DYT1 gene in the Ashkenazi population, suggests that these loci are within $1-2 \mathrm{cM}$ of the DYT1 gene. ${ }^{9}$ In the present study genetic analysis was carried out with the microsatellite markers around the DYT1 locus in a Swedish family with late onset idiopathic torsion dystonia.

\section{Methods}

NEUROLOGICAL EXAMINATION

Family members willing to participate in this study were given on site neurological examination. Most of the family members with abnormal neurological signs agreed to be videotaped for evaluation by ourselves and collaborators at the Dystonia Clinical Research Center at the Neurological Institute, New York, USA. All neurological signs, regardless of their relation to torsion dystonia, were recorded. Venous blood samples were shipped by air to the molecular Neurogenetics Unit, Massachusetts General Hospital, Boston, USA, for DNA analysis. Members were classified as affected or not affected by torsion dystonia. Only those considered unanimously and unequivocally to have dystonia and three obligate gene carriers with minor signs of dystonia were considered affected (A and MSE in table 1). Others were classified as unaffected and one person (III-6) with possible dystonia as unknown. Age of onset was determined as the first occurrence of involuntary movements as noticed by the patients or their relatives.

DNA METHODS, PROBES AND, POLYMORPHISMS ANALYSIS

DNA was extracted from lymphoblast lines or peripheral blood. Analysis of microsatellite polymorphisms for ASS, D9S62a (32/37), D9S62b (1290/1301), and D9S63 (28/34) loci were carried out on genomic DNA using oligonucleotide primer pairs by the polymerase chain reaction to amplify the repeat containing region. ${ }^{10}$ 
Table 1 Family members (family 11 of Larsson and Sjögren ${ }^{3}$ ) used in linkage analysis

\begin{tabular}{|c|c|c|c|c|c|c|c|}
\hline $\begin{array}{l}\text { Pedigree } \\
\text { designation }\end{array}$ & $\operatorname{Sex}$ & Status & $\begin{array}{l}\text { Birth } \\
\text { year }\end{array}$ & Initial signs & Distribution at examination & Age of onset & $\begin{array}{l}\text { Age at } \\
\text { examination }\end{array}$ \\
\hline II:1 & $\mathbf{F}$ & UAE & 1916 & & & - & 68 \\
\hline II: 3 & $\mathbf{F}$ & $\mathrm{AE}$ & 1919 & Dysarthria & Generalised & 17 & 64 \\
\hline II: 4 & $\mathbf{M}$ & UAE & 1920 & & & - & 65 \\
\hline III:5x & $\mathrm{F}$ & UAE & 1923 & & & - & 63 \\
\hline II: $7 x$ & $\mathbf{M}$ & UAE & 1923 & & & - & 63 \\
\hline II $: 8$ & $\mathrm{~F}$ & $\mathrm{AE}$ & 1923 & Dystonia & Generalised & 42 & 62 \\
\hline II: 9 & $\mathrm{~F}$ & UAE & 1925 & & & - & 57 \\
\hline II: 11 & F & MSE & 1926 & Scoliosis & Scoliosis & - & 66 \\
\hline II: 13 & $\mathrm{~F}$ & $\mathrm{AE}$ & 1927 & Blepharospasm & Multifocal: face, arm & 50 & 57 \\
\hline II: 14 & $\mathbf{F}$ & UAE & 1930 & & & - & 62 \\
\hline III: 15 & $\mathbf{M}$ & MSE & 1931 & Increased blinking & Multifocal: face, arm & 25 & 54 \\
\hline II: $16 \mathrm{x}$ & $\mathrm{F}$ & UAE & 1933 & & & - & 53 \\
\hline II: 17 & $\mathrm{M}$ & UAE & 1932 & & & - & 51 \\
\hline III:18 & $\mathrm{F}$ & UAH & 1935 & & & - & - \\
\hline III:2 & $M$ & UAE & 1945 & & & - & 40 \\
\hline III:3 & $M$ & $\mathrm{UAE}$ & 1947 & & & - & 38 \\
\hline III: $4 x$ & $\mathrm{~F}$ & $\mathrm{UAE}$ & 1946 & & & - & 40 \\
\hline III: 6 & $\mathbf{F}$ & PAE & 1952 & & & - & 33 \\
\hline III:7 & $\mathbf{M}$ & $\mathrm{AE}$ & 1958 & Blepharospasm & Multifocal: face, larynx, arm & 18 & 27 \\
\hline III: $8 x$ & $\mathbf{M}$ & UAE & 1948 & & & & 44 \\
\hline III: 9 & $\mathrm{~F}$ & MSE & 1948 & Increased blinking & Multifocal: face, larynx, leg & 30 & 38 \\
\hline III: 10 & $\mathbf{M}$ & $\mathrm{AE}$ & 1948 & Arm dystonia & Generalised & 26 & 36 \\
\hline III: 11 & $\mathrm{~F}$ & UAE & 1952 & & & 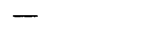 & 34 \\
\hline III: 12 & $\mathbf{M}$ & $\mathrm{AE}$ & 1960 & Blepharospasm & Focal: face & 18 & 25 \\
\hline III: 13 & $\mathrm{~F}$ & UAE & 1964 & & & - & 22 \\
\hline IV:1 1 & $\mathbf{M}$ & UAE & 1970 & & & - & 15 \\
\hline IV:2 & $\mathbf{M}$ & UAE & 1972 & & & - & 13 \\
\hline IV:3 & $\mathrm{F}$ & UAE & 1971 & & & - & 14 \\
\hline IV:4 & $\mathrm{F}$ & UAE & 1974 & & & - & 12 \\
\hline IV:5 & $\mathbf{M}$ & $\mathrm{AE}$ & 1971 & Arm & Multicofal: arm, leg & 20 & 20 \\
\hline IV:6 & $\mathbf{M}$ & UAE & 1974 & & & - & 11 \\
\hline IV:8 & $\mathrm{F}$ & UAE & 1977 & & & - & 9 \\
\hline
\end{tabular}

$\mathrm{A}=$ affected; $\mathrm{UA}=$ unaffected; $\mathrm{PA}=$ possibly affected; $\mathrm{MS}=$ minor signs; $\mathrm{E}=$ by examination; $\mathrm{H}=$ by history; $\mathrm{x}=$ spouse.

LINKAGE ANALYSIS

Linkage analysis for dystonia to marker was performed with the MLINK and LINKMAP options of the LINKAGE package version $5 \cdot 2 .{ }^{13}$ Parameters for the age of onset correction were established with data from this family (figure). Autosomal dominant inheritance of a rare gene (frequency of $0.01 \%$ ) was assumed for dystonia. Recent studies of idio- pathic torsion dystonia in Ashkenazi Jewish families $^{112}$ and non-Jewish, North American families $^{8}$ indicate penetrance between 0.30 and 0.45 . In this Swedish kindred, however, penetrance seems to be nearly complete. Thus we used an intermediate penetrance estimate of $0 \cdot 75$.

Linkage analysis between the dystonia gene and marker loci was assessed at values of

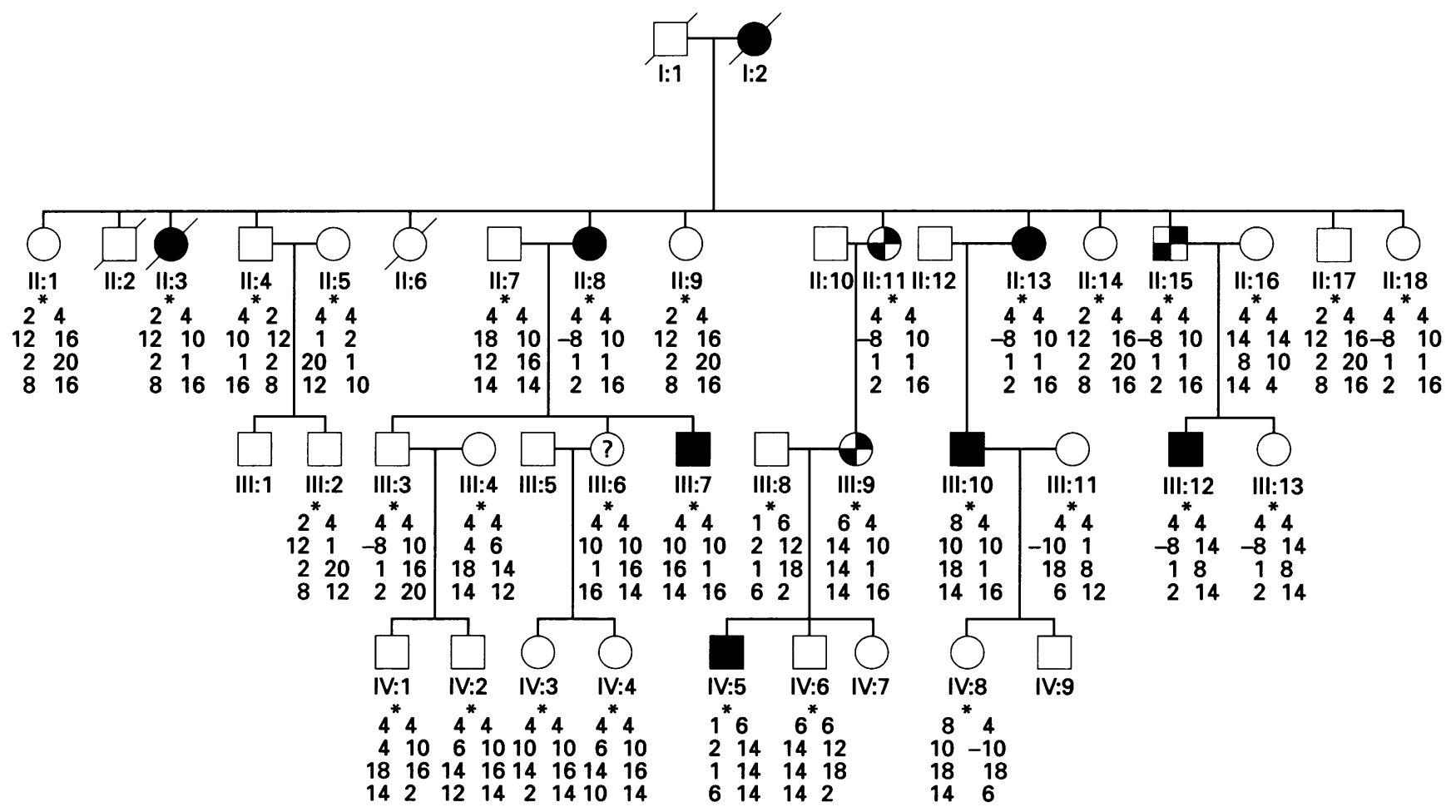

Pedigree of a Swedish family with autosomal dominant idiopathic torsion dystonia with late onset. The symbol (*) in the pedigree indicates members included in the linkage analysis. Black symbols denote affected persons, unfilled symbols denote healthy members, broken symbols denote minor signs, ? denotes possible case of idiopathic torsion dystonia, slashed symbols denote deceased person. Haplotypes, including markers D9S62a, D9S62b, D9S63, and Ass, are shown for each family member analysed. 
theta from 0 to 0.30 ( 0 to $30 \%$ recombination). Exclusion within a given region around the marker gene was considered significant if the Lod score was $<-2.0$; a positive Lod score of $>+3$ would be considered significant evidence in favour of linkage.

\section{Results}

CLINICAL AND GENEALOGICAL DATA

Most affected members were found in one branch of the family. Seven family members had unequivocal signs of torsion dystonia, three obligate gene carriers had minor signs of dystonia, and one member had possible dystonia. Another family member living in Canada (II:18) was unaffected by history, and included in the linkage study (table 1). An extended and revised version of the original pedigree ${ }^{3}$ is presented (figure). Only the part of the family in which cases with dystonia have been found is included in the pedigree. According to the present examination, parent to child transmission in cases with definite dystonia was found in two cases (figure), II:8 to III:7 and II:13 to III:10. Parent to child transmission was also found in obligate gene carriers with minor dystonia signs, II:11 to III:9, III:9 to IV:5, and II:15 to III:12.

\section{LINKAGE ANALYSIS}

Using the subset of the family shown in the figure pairwise linkage analysis between dystonia and four 9q polymorphisms: D9S62a, D9S62b, D9S63, and ASS, all gave negative values at theta $=0.0$, but did not show significant exclusion around these loci (table 2). Still construction of haplotypes across the region spanned by the markers showed obligate recombination in two members with definite dystonia, IV:5 and III:12 (figure), which contribute to the negative Lod scores. Multipoint analysis was also performed, with an intervening distance of $1 \mathrm{cM}$. As expected, the entire region between these markers was excluded for linkage, with Lod scores $>-5.00$ across the region (data not shown).

\section{Discussion}

A gene for idiopathic torsion dystonia in a non-Jewish kindred with autosomal dominant inheritance of early onset dystonia has been located on chromosome 9q34, with linkage to the gene encoding gelsolin (GSN) ${ }^{6}$ This gene has also been implicated in seven non-Jewish families with typical early onset dystonia. In an initial study, linkage analysis using DNA

Table 2 Pairwise linkage analysis of adult onset idiopathic torsion dystonia with the four markers closest to the DYT1 gene on chromsome $9 q$

\begin{tabular}{lllllll}
\hline \multirow{7}{*}{ Marker } & \multicolumn{7}{l}{ Lod score at $\theta$} \\
\cline { 2 - 7 } & 0.0 & 0.01 & 0.05 & \multicolumn{1}{ll}{0.1} & 0.2 & 0.3 \\
\hline D9S62a & -4.01 & -1.73 & -0.71 & -0.29 & 0.01 & 0.04 \\
D9S62b & -6.02 & -1.29 & -0.02 & 0.40 & 0.57 & 0.41 \\
D9S63 & -2.82 & -0.74 & -0.04 & 0.22 & 0.36 & 0.28 \\
ASS & -6.19 & -1.19 & 0.04 & 0.43 & 0.57 & 0.40 \\
\hline
\end{tabular}

$\theta=$ recombinant factor. polymorphisms in 12 Ashkenazi Jewish families showed close linkage with the gene encoding argininosuccinate synthetase (ASS), located in this same $9 \mathrm{q} 34$ region. ${ }^{7}$ Obligate recombination events in several Ashkenazi Jewish families delineate the area containing the DYT1 gene to a $6 \mathrm{cM}$ region bounded by loci AK1 and ASS. ${ }^{9}$ It is assumed that the gene responsible for idiopathic torsion dystonia in the non-Jewish families and in the Ashkenazi Jewish families is the same. ${ }^{714}$ Recently it has been shown that most nonJewish families with early onset dystonia map to this same locus ${ }^{8}$; exceptions, exist, however. ${ }^{15}$

In 1992 Ozelius et al reported linkage disequilibrium between an extended haplotype at $9 q$ loci ABL-ASS and the DYT1 gene in the Ashkenazi population suggesting that these loci were within 1 to $2 \mathrm{cM}$ of each other. ${ }^{9}$ Typing of additional markers in this region in affected Ashkenazi Jews indicates that most early onset cases result from a single founder mutation in this population, ${ }^{16}$ whereas most late onset cases result from other mutations in this or other gene loci. The DYT1 region was recently excluded in adult onset families with idiopathic torsion dystonia from the United States ${ }^{15}$ and British and French families. ${ }^{18}$ The gene for a Swedish familial dystonia with myoclonic jerks responsive to alcohol was also excluded from the DYT1 region. ${ }^{19}$ Recently, a form of dopa responsive dystonia has been mapped to chromosome $14 \mathrm{q}^{20}$

In the present study microsatellite markers localised to the DYT1 region on chromosome 9 were examined in 32 members in a Swedish family variant of adult onset idiopathic torsion dystonia. Negative Lod scores spanning the gene region and two obligate recombinant events excluded the DYT1 region in this family. These data support genetic heterogeneity in idiopathic torsion dystonia, indicating at least one additional locus for the adult onset form.

Chromosomal localisation and subsequent identification of the genes responsible for idiopathic torsion dystonia should lead to more effective treatment for this disorder. A genomic search to find the gene responsible for idiopathic torsion dystonia in this Swedish family with adult onset is underway.

This work was supported by grants from the Dystonia Medical Research Foundation, USA, the Henry J Kaiser Family Foundation NINDS, the Swedish Multiple Sclerosis Society Borgströms Foundation, Sweden, and the Swedish Medical Research Council (Project No -09745).

1 Nutt JG, Muenther MD, Melton III LJ, Aronson A, Kurland LT. Epidemiology of dystonia in Rochester, Minnesota. In: Marsden CD, Fahn S, eds. Movemen disorders. London: Butterworths, 1987:361-5.

2 Fahn S, Marsden CD, Calne DB. Classification and investigation of dystonia. In: Marsden CD, Fahn S, eds. Movement disorders. London: Butterworths, 1987 332-58.

3 Larsson T, Sjögren T. Dystonia musculorum deformans. A genetic and clinical population study of 121 cases. Acta Neurol Scand 1966;suppl 17:1-232.

4 Forsgren L Holmgren G, Almay BGL, Drugge U. Autosomal dominant torsion dystonia in a Swedish famAutosomal dominant torsion dystonia in a Swedish family. In: Fahn S, Marsden CD, Calne DB, eds. Advances in Neurology, Vol. 50 Dystonia 2. New York: Raven 5 Burke RE, Fahn S, Marsden CD, Bressman SB, 
Moskowitz C, Friedman J. Validity and reliability of a rating scale for the primary torsion dystonias. Neurology rating scale for

6 Ozelius LJ, Kramer PL, Moskowitz CB, et al. Human gene for torsion dystonia located on chromosome 9q32-34. Neuron 1989;2:1427-34

7 Kramer PL, de Leon D, Ozelius LJ, et al. Dystonia gene in Ashkenazi Jewish population is located on chromosome 9q32-34. Ann Neurol 1990;27:114-20.

8 Kramer P, Heiman G, Gasser T, et al. The DYT1 gene on $9 \mathrm{q} 34$ is responsible for most cases of early-onset idiopathic torsion dystonia (ITD) in non-Jews. $A m$ Hum Genet 1994;55:468-75.

9 Ozelius LJ, Kramer PL, de Leon D, et al. Strong allelic association between torsion dystonia gene (DYT1) and loci on chromosome $9 \mathrm{q} 34$ in Ashkenazi Jews. Am $\mathcal{f}$ loci on chromosome 9q34

10 Henske E, Ozelius L, Gusella J, Haines J, Kwiatkowski D. A high resolution linkage map of human $9 q 34 \cdot 1$. Genomics 1993;17:587-91.

11 Bressman SB, de Leon D, Brin MF, et al. Idiopathic torsion dystonia among Ashkenazi Jews: evidence for autosomal dominant inheritance. Ann Neurol 1989;29. 612-20.

12 Pauls DL, Korczyn AD. Complex segregation analysis of dystonia pedigrees suggests autosomal dominan inheritance. Neurology 1990;40:1107-10.
13 Lathrop GM, Lalouel JM. Easy calculations of lod scores and genetic risks on small computers. Am $\mathcal{f}$ Hum Genet 1984;36:460-65.

14 Kwiatkowski DJ, Ozelius L, Kramer PA, et al. Torsion dystonia genes in two populations confined to a small region on chromosome 9q32.34. Am f Hum Genet 1991;49:366-71.

15 Bressman SB, Hunt AL, Heiman GA, et al. Exclusion of the DYT1 locus in a non-Jewish family with early-onset dystonia. Mov Dis 1994;9:626-32.

16 Bressman SB, de Leon MS, Kramer PL, et al. Dystonia in Ashkenazi Jews: clinical characterization of a founder mutation. Ann Neurol 1994;36:771-7.

17 Bressman SB, Heiman GA, Nygaard TG, et al. A study of idiopathic torsion dystonia in a non-Jewish family: evidence for genetic heterogeneity. Neurology 1994;44: 283-7.

18 Warner TT, Fletcher NA, Davis MB, et al. Linkage analysis in British and French families with idiopathic torsion dystonia. Brain 1993;116:739-44.

19 Wahlström J, Ozelius L, Kramer P, et al. The gene for familial dystonia with myoclonic jerks responsive to alcohol is not located on the distal end of 9q. Clin Gener 1994;45:88-92.

20 Nygaard T, Wilhelmsen KC, Risch NJ, et al. Linkage mapping of dopa-responsive dystonia (DRD) to chromosome 14q. Nature Genetics 1993;5:386-91.

\section{NEUROLOGY IN LITERATURE}

\section{Some doctor and patient opinions}

Mrs Trundle's physician wisely allows his patient the last word in her management, aware no doubt that any decision can have no adverse effect on the outcome of her illness. Dickens makes an astute comment on the way in which a patient's class and position influences the doctor's use of disease terminology. We have all encountered the type of physician Wilkie Collins describes in The moonstone. Somehow, often by a devious route, they arrive at the correct diagnosis.

Arnold Bennett's description of a despondent young doctor could have been written today, showing that intense competition in the professions should not be regarded as a modern phenomenon.

Franklin, in The horse's mouth, has a decidedly jaundiced view of the medical profession, which, from his comments, does not seem entirely unreasonable.

Charles Dickens, 1836-7, The Pickwick papers

Hereupon, Mr Trundle called in the doctor, and the doctor said Mrs Trundle ought to know best how she felt herself, to which Mrs Trundle replied that she felt herself quite equal to it, and that she had made up her mind to go; upon which the doctor, who was a wise and discreet doctor, and knew what was good for himself as well as for other people, said that perhaps if Mrs Trundle stopped at home she might hurt herself more by fretting, than by going, so perhaps she had better go.

Charles Dickens, 1841, Barnaby Rudge

"The door will be opened immediately," he said. "There is nobody but a very dilapidated female to perform such offices. You will excuse her infirmities? If she were in a more elevated station of society, she would be gouty. Being but a hewer of wood and drawer of water, she is rheumatic. My dear Haredale, these are natural class distinctions, depend upon it."

Charles Dickens, 1864-5, Our mutual friend

Too late to know for certain, whether injuries received before or after death; one excellent surgical opinion said, before; other excellent surgical opinion said, after.

Wilkie Collins, 1868 , The moonstone

In his medical practice he was a more prudent man; picking up his discretion (as his enemies said) by a kind of instinct, and proving to be generally right where more carefully conducted doctors turned out to be wrong.

Wilkie Collins, 1883, Heart and science

"Let me hear how you like the scientific people at close quarters, and let me give you a useful hint. When you meet in society with a particularly positive man, who looks as if he was sitting for his photograph, you may safely set that man down as a professor."

Amold Bennett, 1910, Clayhanger

Charlie was about to reply in accents of disdain: "Not me!" but his natural politeness stayed his tongue. "I hardly think so", he said. "Too much competition here. So there is everywhere, for the matter of that." The disillusions of the young doctor were already upon Charlie. And yet people may be found who will assert that in those days there was no competition, that competition has been invented during the past ten years.

Arnold Bennett, 1912, Buried alive

On the other side of the door, dressed in frock coat and silk hat, there stood hesitating a tall, thin, weary man who had been afoot for exactly twenty hours, in pursuit of his usual business of curing imaginary ailments by means of medicine and suggestion, and leaving real ailments to nature aided by coloured water.

foyce Cary, 1944, The horse's mouth

"It's only that I never could stand doctors. Well, they've got to find something wrong haven't they? It's only professional. But there was my friend Mrs Blonberg, just opposite - she used to have a little pain-I'm sure it was no more than I've had myself and thought nothing of, and she went to the doctor, and the next thing she was in hospital and they cut her up on Monday and we buried her yesterday."

"Been to the doctor?"

"Doctor? You can have doctors. What do they know? What did they do for your rupture?" "Well, they say I'm an exceptional case." "So am I. That's what they always say. That's what you'll die of when your guts get another crick in them. That's what my ma died of. She was an exceptional case. Nobody's never seen anything like it before. Ya. Doctors." 